\title{
The political innovation of the European Union*
}

\author{
Daniel Innerarity \\ Professor for Political Philosophy, "Ikerbasque" Researcher, \\ University of the Basque Country UPV/EHU, \\ Director of the Institute for Democratic Governance
}

\begin{abstract}
Summary: I. Introduction.-II. European identity: an "us" made up of others. - III. European spaces: margins that do not set limits. IV. Governing without sovereignty: beyond the national state.-V. European economic governance: mutualization of risks. - VI. European citizenship: a plurality of loyalties. - VII. A globalized Europe: a sort of "us" without others. - VIII. Conclusion.
\end{abstract}

\begin{abstract}
The political innovation represented by the European Union can only be understood if the perspective and the concepts inherent to the national state are abandoned. This paper aims at examining such innovation from an analysis of the European identity, weaker than usually believed, in historical and geographical terms, as well as from the understanding of the EU's original methods of governance, thus conceiving it as an experiment of global reach.
\end{abstract}

Keywords: European identity, governance, globalization.

Resumen: La innovación política que representa la Unión Europea solo puede ser entendida si abandonamos la perspectiva y los conceptos propios del estado nacional. Este artículo propone examinar dicha novedad a partir de un análisis de la identidad europea en términos históricos y geográficos, más débil de lo que suele creerse, desde la comprensión de sus originales métodos de gobernanza y concibiendo la UE como un experimento de alcance global.

Palabras clave: Identidad europea, gobernanza, globalización.

\section{Introduction}

Europe is often said to have communication problems. I would like to begin this paper by saying that this is not surprising, taking into account the very nature of this political undertaking. Jacques Delors himself said that what we are facing is an unidentified political object; we should then not be at all surprised that public perception is often blurred and confused.

* Recibido el 2 de noviembre de 2012, aceptado el 17 de diciembre de 2012. 
This perplexity would be minimal if we were dealing with a configuration that could be guided by the traditional categories of the nation state or international relations, if we were building a national state on a larger scale or intensifying relations between sovereign states. However, this integration process is unique and requires original concepts and actions. For this reason, my reflections on Europe are not so much on the way to communicate as on what must have been previously understood to be able to communicate; they are not instructions for use but guidelines for understanding.

A lot has been said about the democratic deficit. However, I believe that Europe's deepest problem is its cognoscitive deficit, our lack of understanding about what the European Union stands for. It is difficult for us to understand that we are facing one of the greatest political innovations in recent history, an authentic laboratory to test a new formula for identity, power or citizenship within the framework of globalization. The crisis behind the failure of the Constitution or the widespread disaffection concerning the possibilities for further integration are mainly due to poor understanding of what we are and what we are doing, or, if you allow me this statement, the lack of a good theory of Europe. The deficit I have mentioned is not a communication problem that can be solved with better marketing techniques. It is a lack of understanding and conviction (among citizens and their government leaders) about the originality, subtlety, meaning and complexity of the European construction. This explains the citizens' fears and the modest ambitions of many of their leaders. The ideas that many people hold about Europe are full of misunderstandings, at the mercy of superficial public opinion: Europe is seen as a supplementary power scale, a strategy to survive in the face of globalization seen as a threat, a political system replicating the nation state model... Frequently, some countries seem to be firm believers in Europe because they appreciate the subsidies they have received while others see Europe as a threat and fail to recognize the opportunity it represents. Both sides have the wrong idea of what Europe stands for, and until this misunderstanding is cleared up, endorsement of the EU's political project will continue to be weak or shallow.

What Europe needs is to know itself and renew its coherence. No progress can be made in political integration if we do not openly tackle the issue of the nature of Europe, if we ignore the deep issues of what it is and what it can be. Needless to say, until this point is clarified, no communication policy within the European Union can be efficient, above all in a mature society where it is increasingly difficult to act without being accountable. As Julia Kristeva ${ }^{1}$ said: Europe must become not just useful

${ }^{1}$ KRISTEVA, J., Crisis of the European Subject, New York: Other Press, 2000. 
but meaningful. Understanding Europe is the first step to give it meaning and direction, to tell the public what should receive their assent after public debate. This clarification may have been considered idle for some time, but it has now become unavoidable to have an idea of Europe which can explain its uniqueness and the possibilities it contains.

I am going to try to demonstrate the European Union's originality in six aspects: 1. The European identity, more complex and diverse than what we tend to think; 2. The European space, with margins rather than limits or borders; 3 . European governance testing a new political structure that goes beyond the nation state and sovereignty; 4. European economic governance, meaning pooling risks; 5 . European citizenship, which has become pluralized and whose endorsement is needed to advance towards greater integration, and 6. A globalized Europe that could serve as a model for an interdependent world. The aim of this paper is to reflect on these six topics (identity, space, government, economy, citizenship and globalization) and explain why Europe, paradoxically, has a poorly defined identity, a space that is not closed, a government that is not sovereign, an economy that shares risks, citizens with a conditional loyalty and a sense of "us" without others.

\section{European identity: an "us" made up of others}

Europe has often been defined from geographic, cultural, historical and political factors supposed to form the basis of a unique civilization and to give rise to a Western model of modernity. However, a closer look shows that the issue of identity is more difficult to define. From the geographic point of view, Europe lacks natural limits: the Atlantic does not separate its shores in absolute terms, above all because of the peculiar relationship between Great Britain and the United States or Spain and Portugal with Latin America; the Mediterranean is a space that separates as much as it unites and relates; towards the East Europe has no clear border. If we understand Europe as a continent, it is even less clear. Paul Valéry aptly described it as a small promontory of $\mathrm{Asia}^{2}$. In this sense, Europe is even less consistent geophysically than, for instance, the Indian subcontinent. In terms of civilization, Europe stretches towards Asia and encompasses a large part of the Mediterranean.

From the historical point of view, Europe is not a uniform civilization that has followed a unique path clearly different from the rest of the world.

2 VALÉRY, P., “Note (ou L’Européen)”, in Euvres. I, Paris: la Pléiade, 1957, pp. 1000-1014. 
Europe's cultural diversity is more than the diversity of the nations forming it. Europe has been formed by the interaction and mutual fertilization of its civilizations. Therefore, it more closely resembles a "constellation of civilizations" 3 than one civilization.

When attempting to effectively identify European s, there is no allencompassing inclusive identity. European s are not especially united and are even less likely to define themselves as opposed to otherness. As Brague said, "the danger for Europe cannot come from outside simply because it cannot consider itself as an inside" 4 . The forces that keep us together are not especially emphatic, nor is that which makes us different from others.

Nor can Europe be defined as the West. The historical roots of Western civilization-Athens, Rome, Jerusalem - were not European in the Western sense of the word. We often forget that Western culture and civilization were originated in the Eastern world. The ancient world was Eastern rather than Western. Classical antiquity and the origins of Christianity were Mediterranean in the sense used by Braudel ${ }^{5}$. The Romans, like the Greeks, did not have a clear sense of European identity, which was more typical of the Middle Ages. Rather, the Romans thought of Rome as the centre of the world. Because of its history, Europe is not the same as the West, and this is especially true in the present time.

Ancient peoples thought that the North-South division was more meaningful than the East-West one. For many years, the Alps stood for a geographical and cultural frontier much more than the Mediterranean, which was considered the centre of civilization. The counter position East versus West originated when the idea of Europe was articulated against Islam in the seventh century. This counter position continued throughout the Middle Ages, in modern times and until the end of the Cold War.

The enlargement of the European Union towards the East is qualitatively different from former enlargements. It is not only a significant increase of member states but also a reshaping of its civilization framework. By moving Europe's borders towards Russia and with the future entry of Turkey, Europe is moving towards Asia and becoming increasingly postWestern and polycentric. This makes it possible to overcome the "little Europe" of the Cold War. Enlargement not only makes Europe larger but also transforms it qualitatively. The fall of the Communist regime did not eliminate the East but reshaped it, a new "East" that is going to be

${ }^{3}$ DELANTY, G. and RUMFORD, C., Rethinking Europe. Social Theory and the Implications of European ization, Routledge, London, 2005, p. 37.

${ }^{4}$ BRAGUE, R., Eccentric Culture: A Theory of Western Civilization, Augustine's Press, South Bend, 2002, p. 185.

5 BRAUDEL, F., La Méditerranée, Flammarion, Paris, 1999. 
increasingly relevant in the new Europe. The fall of the Berlin Wall in 1989 meant the disappearance of the sharp distinction East versus West and gave rise to a new European era oriented toward building a multipolar world.

The answer to the recent debate on "Europe's Christian roots" can best be understood within these premises. If European identity is not codified in a cultural package, it cannot be defined in terms of religious identity, either. Europe's identification with Christianity-which comes from the Habsburgs and was used at the time to oppose the Ottoman Empiredoes not do justice to Europe's religious pluralism either in historical or sociological terms. It does not succeed in explaining the significance the religious dimension has had and still has in Europe. The problem is not admitting or just forgetting the importance Christianity has had as one of Europe's foundations. To begin with, this acknowledgement cannot be fair if it forgets that there are other religions that have contributed to shape our constituent identity. This pluralism (which cannot be understood without the Jewish or Islamic influence) is required by our history. However, this pluralism is also demanded by the current configuration of our societies, home to, for example, over fifteen million Muslims. This said, the core issue lies in the fact that the definition of citizenship cannot be determined by a reference to a culture or religion. Europe will certainly have to adjust to a pluralism that does not only refer to diverse religions but to the diverse meanings religion has for our fellow citizens. But we will have to do it within this dissociation between the identitarian and the public that has allowed, like no other, the coexistence of beliefs and lifestyles.

Europe is not a lifestyle, a people, a civilization or a super-state. Rather, it is a particularly original construction allowing the possibility of accepting legally binding rules that stem from the articulation between spaces that are neither homogeneous nor wholly unified. In this way, the EU differentiates itself from the traditional constitutionalism that called for unity of demos, which very often also entailed political, cultural or linguistic unification. This dissociation between the identitarian and the political constitutes one of its most interesting innovations. This contemplates the possibility of a democracy without demos or with diverse demoi, a vaguely defined, not clearly limited and porous people, not necessarily opposed to others.

This difficulty to describe Europe in cultural terms that refer to a common history, a defined common territory or a set of shared values makes the configuration of a European public space particularly important: Europe must be seen as a conversation, as a discursive space that does not need determining bases but opportunities for dialogue

If one had to stress a particularly characteristic value in the midst of this pluralism, I would say that the starting point would be Montesquieu's sharp remark when he said that Europe has always been especially interested in 
knowing what others think about us. I think it is this will to see ourselves from the outside, rather than a supposed defence of something exclusive, that is at the origin of our best constructions. And, what if our fundamental values were a set of habits that have shaped an identity that continuously makes us keep at bay from our own identity? Self-relativization, reflexivity, distance from oneself, curiosity, respect, interest in compatibility, willingness to cooperate and recognition are the descriptive features of a weak kind of identity without which the European experiment would not be possible.

\section{European spaces: margins that do not set limits}

The European space is a key issue to understand the meaning of European integration. From this point of view, we can also come across some peculiarities that are essential if one needs to understand the innovation represented by the European space. The European Union is a singular space. As a unified political space it represents an innovation that demands the reconsideration of the premises concerning the conventional conception of territoriality. It is not surprising that the EU has come up with some new spatial terms: networks, variable geometry and multiple levels, among others. This innovation reveals that we are rehearsing the possibility of an organization of the political space beyond certain territorial premises of the nation-state ${ }^{6}$.

The first category that may be eroded by the new constellation is the idea of a delimited space. We are used to thinking of political spaces as delimited, articulated into states and divided by borders. In the case of the EU what we have, both inwards and somehow outwards, is a plurality of spaces that cross and overlap each other. The European space has margins or 'borderlands' rather than limits. From a geopolitical point of view, its Eastern or Mediterranean borders are not properly fixed limits, but margins that do not limit, relatively porous thresholds, dynamic zones where ways of connectivity and discontinuity are articulated. Margins do not necessarily divide spaces; they can also unify them in some way and behave as points of suture ${ }^{7}$. Something that also occurs in other places in the world is particularly intense in Europe. Globalization means a continuous crossing of spaces, a dialectics of limitation and delimitation. Rather than being

${ }^{6}$ BARRY, A., Political Machines: Governing a Technological Society, Athlone Press, London, 2001.

7 HANSER, P., "Fixed Borders or Moving Borderlands? A New Type of Border for a New Type of Entity", in ZIELONKA, J., Europe Unbound: Enlarging and Reshaping the Boundaries of the European Union, Routledge, London, 2002, p. 40. 
reduced to a divisory line, discontinuities take place within a space ${ }^{8}$. This is the reason why borders have lost their old strategic role. Therefore, the outbreak of new conflicts does not take place in contact areas, but inside the supposedly delimited spaces themselves.

From this point of view, one can state that the idea of margins resembles rather the limes of an empire than the traditional border of modern states. In this sense it seems to be appropriate to compare the EU and the old empires, to which it may be bear more resemblance than to national states from the point of view of the organization of space. The issue is that contact zones do not delimit spaces in the same way as the borders that safeguarded territorial integrities. Unlike limits, margins do not make a complete distinction between those inside and those outside; they do not delimit them in a definite, sharp way. Margins are spaces that are neither fully integrated nor absolutely exterior; and they cannot be tamed. The nature of margins manifests itself in their expandable character or in the possibility of maintaining privileged relationships with certain environments. When it comes to understanding the kind of borders in the EU, it is very significant to consider the argument that the enlargement took place because there were no reasons for opposing it. Due to its peculiar identity, the EU lacks uncontroversial arguments to set its limits.

I think that in the current discussions on the future of Europe, one tends to neglect this sort of decisive issues. For example, debates on 'integration' tend to ignore other key issues that belong to its spatial shape: provided Europe is a network, internal coherence is as important as the articulation established with its surroundings and the rest of the world. The European space cannot be properly understood if it is reduced to a matter of integration-domestic-and if its connectivity is neglected-external. This is what makes it more complex and dynamic. It is in fact this idea of 'European margins' that suggests there is another logic in the process of integration: its incapacity to either wholly unify its political, economic or social spaces or to limit them outwards stems from two different facts. First, that the EU is less separated from the rest of the world than we usually think, and second, that globalization does not make it different from other regions in the world, but means its interpenetration ${ }^{9}$. This may be the reason why it makes sense to define Europe itself, the whole of it, as "borderland" 10 , in the sense that Europe itself is both a crossroads and

8 SASSEN, S., "Spatialities and temporalities of the global: elements for a theorization", in APPADURAI, A. (ed.), Globalization, Duke University Press, Durham, 2001.

9 DELANTY, G. and RUMFORD, C., op. cit., p. 134.

${ }^{10}$ BALIBAR, E., We the People of Europe: Reflections on Transnational Citizenship, Princeton University Press, 2004, p. 220. 
a site of conflict, a space where global interdependences are particularly intense.

The European Neighbourhood Policy (ENP) constitutes the clearest manifestation of the EU's interest in acting beyond its immediate sphere and assume its responsibilities concerning the governance of civilization. The Commission is growingly aware of the fact that, as a consequence of globalization, financial flows, communication networks and markets, rigid limits are a source of potential instability rather than a guarantee for security. The EU's response to this situation is its intention to develop an area of prosperity and friendly neighbourhood - 'a ring of friends'-by means of cooperative relationships ${ }^{11}$. By acknowledging the interrelationship between its inner development and the external environment, the EU admits it cannot think of itself on the basis of a rigid division between the internal and the external. "Our task is to promote a ring of well governed countries to the East of the European Union and on the borders of the Mediterranean with whom we can enjoy close and cooperative relations"12. The EU internal security cannot be reduced to a matter of control of external borders. Little by little, we have come to realize that we have to move from the concept of Europe as a fortress to a topography of the border areas that reduces the separation between Europe and the world.

\section{Governing without sovereignty: beyond the national state}

It is difficult to think of the EU in terms different from those of the state, to think of it as something more than a peculiar variation on the same pattern. However, we are neither facing a super-state nor a simple articulation of states. For the forerunners of the idea of Europe, it was clear that Westphalian order, based on the principle of unlimited sovereignty of states, in which relations are governed by force, had to be replaced by common regulatory principles. The needed to go beyond the merely declaratory principles, such as the Universal Declaration of 1948, and make the states commit themselves in such a way that those principles could be invoked and the states punished if their performance threatened democracy and fundamental rights. This internationalisation of fundamental rights meant the endorsement of a primordial rule for states, similar to the

11 EUROPEAN COMMISSION, Communication from the Commission to the Council and the European Parliament: "wider Europe - neighbourhood: a new framework for relations with our eastern and southern neighbours" COM, 104 final, Brussels, 2003, p. 4.

12 EUROPEAN COUNCIL, "A secure Europe in a better world: European security strategy”, Brussels, 12 December, 2003. 
ones imposed by democratic revolutions. It also pointed to transnational constitutionalism.

Since then, the evolution of Europe has taken place hand in hand with a discussion concerning its nature. Supporters of sovereignty understand Europe as a simple federation of states, or at least, would like to limit it in that direction. Federalists highlight that, in fact, judges have already adopted interpretative criteria closer to those of Constitutional Courts than to those of international jurisdiction. The authority of the European institutional system enjoys is stronger than that of classic international law, though less stable than that resulting from a state Constitution. In any case, to understand the EU it is necessary to overcome this dilemma. An unprecedented kind of post-state political power is built on the basis of existing structures containing elements of federation and confederation.

It is true that the European Union was born in part so as to create a framework of action that allowed all states to cope with the demands of a globalised economy. The Union would provide what states could no longer guarantee and in this way states would be saved ${ }^{13}$. However, this saving has only been possible by means of radically modifying the scenario defined by states, which have stopped being sovereign actors. National states can no longer be the core of the analysis to understand what Europe means. The radical novelty brought about by the European Union cannot be understood when considered on the basis of the old conceptual framework, which considers institutional expansion and widening of spaces of action as a way to weaken particular sovereignties. National categories cannot but provide a negative definition of Europe. Methodological nationalism and its obsession with the state prevents the possibility of conceiving what is new in Europe, which limits perspectives and draws attention towards false alternatives and zero-sum games. On the basis of these categories Europe is understood either as a "super-state" 14 that would eliminate nations or as a federation of national states that would defend their respective sovereignties with particular zeal.

In order to get an idea of the innovation involved, it is necessary to understand that European integration as a whole is a process resulting from the tension between intergovernmentalism and supragovernmentalism, a movement in which states play the leading roles but goes beyond them. The successive allocation of policies, competences and spaces for action at a European level, and the implementation of decision making processes that can no longer be controlled by the member states alone but that have more

13 MILWARD, A.S., The European Rescue of the Nation-State, Routledge, London, 1994.

14 SIEDENTOP, L., Democracy in Europe, Columbia University Press, New York, 2007. 
to do with their own dynamics create a structure that is neither a replica of national states nor a variation of international organizations ${ }^{15}$. The best definitions of the European Union have tried to label its radical innovative character under a new category: a network or "set of networks"16 but also a "multi-level governance" or "consociative system"17. It has also been said that Europe is "a balance of imbalances"18. The institutional and procedural innovations of the European experiment stem from a way of governing that is based on coordination and interdependence. They correspond to the type of organization that belongs to a society that can no longer put up with being governed from a rigid centre, with a strict hierarchy aimed at producing homogeneity.

The EU has become a regulatory framework that undermines the sovereignty of the states ${ }^{19}$. According to the European Court of Justice there is even a limited possibility of amending founding treaties and, therefore, a drastic limitation to the sovereignty of states. The primacy principle, which was not explicitly reflected in the founding treaties, has become an undisputable statement supported by jurisprudence. It is even argued whether there is a right of secession without the consent of all others and without complete negotiation. Although the Union lacks coercive instruments, one has to bear in mind that it is an original political and legal system whose effectiveness does not rely on violence, but on interdependence ${ }^{20}$.

In any case, due to its complex government structure, the European Union has modified the way to understand and exercise power. The idea itself of sovereignty, traditionally absolute and non-shareable, transforms

15 TÖMMEL, I., Das politische System der EU, Oldenbourg, München, 2003, p. 54.

16 KEHOHANE, R. and HOFFMANN, S., "Conclusions: Community politics and institutional change", in WALLACE, W. (ed.), The Dynamics of European Integration, Printer, London, 1990, pp. 276-300; CASTELLS, M., La era de la información (3). Fin del milenio, Alianza, Madrid, 2001; KOHLER-KOCH, B., The Transformation of Governance in the European Union, Routledge, London, 1999; ANSELL, C., "The Network Polity: Regional Development in Western Europe", in Governance 13, 2003, pp. 303-333.

17 MARKS, G. et alter, Gobernance in the European Union, Sage, London, 1996; GRANDE, E., "Multi-Level Governance: Institutionelle Besonderheiten und Funktionsbedingungen des europäischen Mehrebenensystems", in GRANDE, E. and JACHTENFUCHS, M., Wie problemslösungsfähig ist die EU? Regieren im europäischen Mehrebenensystem, Nomos, Baden-Baden, 2000; HOOGE, L. and GARY, M., Multi-Level Governance and European Integration, Rowman \& Littlefield, Lanham, 2001; BENZ, A., Der moderne Staat. Grundlagen der politischen Analyse, Oldenburg, München, 2001.

18 HOFFMANN, S., The European Sysiphus. Essays on Europe, Westview Press, Boulder, 1996.

19 MAJONE, G., Regulating Europe, Routledge, London, 1996.

20 DÍEZ-PICAZO, L., "Les pièges de la souveraineté" in DEHOUSSE, R. (ed.), Une constitution pour l'Europe, Presses de Sciences Po, Paris, 2002, p. 65. 
itself and results into what some have called "complex sovereignty" ${ }^{21}$, that is, the paradoxical possibility that sovereignty losses can provide sovereignty gains. It is difficult to understand this peculiarity of the UE's regime when sovereignty is thought of in the traditional way, on the basis of which one gains what someone else loses. Europe is a cooperation game that does not leave those who take part in it untouched, but that transforms them in such way that they accept the institutionalised constrictions of collective action. Europe disciplines interests and modifies preferences inasmuch as it inserts them into interdependence networks and they are subject to permanent discussion and revision. The genius of the "community method" consists in its capacity to avoid single leadership, hegemony or centralization.

Whether the European experiment fails or succeeds is something that will not be decided upon because we have a clear idea of what we are involved in. However, a process of such magnitude cannot be carried out without a set of categories that properly interpret the situation. Our main challenge lies in abandoning the concepts focused on the traditional idea of state and developing an alternative understanding of the relationships between states, nations and societies. In order to understand Europe properly we have take some distance from the concept of state. The European Union is not a state, but a new form of organizing political power for which the concept of state is not suitable. European integration has undermined the old argument according to which democracy can only work in nationally homogeneous territories, the only ones capable of shaping a common identity and the indispensable mutual trust. Although the discussion on democracy in the EU is still unfinished, integration has allowed for an evaluation of the issue of democracy at the level of a discussion on the possibility of a pluralist order beyond the nation state.

At the same time, the concept of sovereignty must expand towards the areas of power in the global age. The traditional notion of sovereignty is not in line with the political project of European citizenship. As things stand, Ulrich Beck is right when he claims that a cosmopolitan Europe is nowadays the latest effective political utopia ${ }^{22}$. As we need to define a new European common good as opposed to the most immediate interests posed by both the capital and the states, European s have an opportunity to discover the great goals of politics.

${ }^{21}$ GRANDE, E. and PAULY, L.W., Reconstituting Political Authority: Complex Sovereignty and the Foundations of Global Governance, University of Toronto Press, Toronto, 2004.

22 BECK, U. and GRANDE, E., Das kosmopolitische Europa. Gesellschaft und Politik in der Zweiten Moderne, Suhrkamp, Frankfurt, 2004, p. 11. 


\section{European economic governance: mutualisation of risks}

When one assesses reality, it is advisable to respect the principle that the severity of the judgment must be proportioned to the difficulty of the task. In the midst of the most complex economic crisis of the history of humankind the European Union has made a series of decisions that have in fact encouraged the process of integration probably out of sheer necessity rather than conviction. The deepest transformations in the history of European integration have been taking place during the past months, as a consequence of the decisions the different European states have been forced to adopt to face the economic crisis. In particular with the outbreak of the crisis of sovereign debt, projects aimed at reinforcing the economic union by means of mutualising its risks occur rapidly at the same time as they make it evident that the European Union is more evolutionary than its critics lamented.

Are we going too fast or too slowly in this process of handing over sovereignty? I am one of those who would go for a higher speed and a more definite support of federalization, but this does not prevent me from admitting, when faced with non-refined criticism addressed at the European Union, that we have made a certain progress that would have been unthinkable of in calmer times. The following example may be enough to keep the restless at ease. Almost a year went by between the agreement of the European Council in Copenhagen (April 1978) and its implementation (March 1979). The aim was to fix some kind of parity between the different local currencies in the EEC in order to reach "a zone of monetary stability in Europe" 23 . The nine countries that then were part of the Union had taken seven years to reach some previous agreement. In 2010, four months were enough to go from divergences to an agreement on EU policy to face the crisis of sovereign debt. In the meantime, there is undergoing discussion as well as expectations that the European Central Bank can play a more significant role in the management of the financial crisis. By means of their guarantee funds, the seventeen countries in the Eurozone and the twentyseven in the EU have implemented a system of budgetary solidarity and, above all, unmistakable tools of budgetary federalism.

It is advisable to assess those advances within their historical context and on the basis of certain inertias that are probably heavier than what would be desirable. The European Union is an association of postnationalist national states. Considered from the perspective of five centuries of modern

23 The Brussels Summit of December 1978 decided to set up a European Monetary System (EMS). It aimed to create a zone of monetary stability in Europe by reducing fluctuations between the currencies of the participating countries. It was put into operation in March 1979. 
and contemporary history, European integration is a true revolution; from the point of view of the urgencies posed by globalization, this integration turns out to be very slow, though. This slow pace can of course be explained because European citizens neither can nor want to break apart from those five centuries of history. Mutualizing twenty-seven sovereignties is an unprecedented process in the history of humankind. It is, no doubt, a process with a clearly universal scope. But, logically, it goes hand by hand with slowness, hesitation, backward steps and deviousness.

What needs to be done is to complete the project of the euro with a true economic government in the Eurozone. The mechanisms of European governance have proved to be dramatically inadequate. On the occasion of the Greek problem it was especially manifested that a monetary union demands true mechanisms of budgetary coordination. We can now perceive the problems resulting from having created a single currency without enough budgetary and political coordination. We do not have the necessary solidarity, either, and generally speaking the rules of the Stability Pact have not been respected. When the 2008 crisis broke out, the EU counted on an unfinished money institution, a weak economic growth, and important private and public debt, together with a lack of agreement concerning the economic, political and strategic decisions to be adopted.

But there is something more serious for the single currency: the Eurozone includes countries with diverging economic paths: exporting Germany focuses on labour costs to the detriment of internal demand; France, on the contrary, maintains its growth on the basis of private consumption; Greece is a service-based economy, little exporting in itself; Spain is rooted on the real estate market. What can be done about this heterogeneous EMU space when divergence stresses particular interests, when transit towards new stages in the cooperation would involve decisions that affect certain deeply rooted commitments in the personality of each and every state and their respective social contracts? It is indeed difficult to ask German taxpayers, for example, to bear the burden entailed by the falsification of Greek figures that allowed them to benefit from very low interest rates or to facilitate the liquidity of Irish banks when we all know their dramatic boost in the 90's was due to European subsidies, but, most of all, to a process of tax dumping away from the rest of Europe.

The relentless pressure of markets on certain countries of the Eurozone is largely due to the fact that the crisis has touched a monetary area of fragile integration. In order to understand the reasons for this fury in the markets it may be useful to wonder why Greek or Irish debt have not been tackled the same way as the debt in Louisiana or California. On January 13, 2010 Standard \& Poor's downgraded California, which had serious repercussions in terms of the conditions to fund its cash requirements. 
However, the dollar was not attacked. There was no announcement of a plan of adjustment of American public finances, even though the weight of California in the United States is heavier than that of Greece in Europe. The United States has a very high public debt problem but, if handled seriously by the authorities, it cannot be subject to speculative attacks with the same intensity as a the Euro, a young currency in a more uncertain environment.

What is the reason for such a different attitude in both cases? The answer has to do with the fact that in the United States economic unity goes beyond the Federal States, a sense of identity which Europe lacks. The markets do not acknowledge the unity of the Eurozone, and this weakens us. Jean-Claude Trichet complained that international investors could neither understand the European decision-making mechanisms nor the historical dimension of the European construction. But one cannot hold this against financial markets, as they are only stating a fact. We are a monetary federation, but we lack the corresponding budgetary federation in terms of the control and monitoring of the implementation of public finance policies. As a general rule, the countries belonging to the Union enjoy a high level of regulation of the financial markets, but to date these mechanisms are not sufficiently and, above all, do not materialize in a given authority that ensures their respect. Therefore, the problem is the lack of economic coherence in the Eurozone and its weak governance. This weakness has become more evident under the impact of the crisis ${ }^{24}$. The Euro is definitely an "unfinished currency" 25 and we are now paying for the asymmetries between the European strong monetary orders and weakly constitutionalized social and democratic rights ${ }^{26}$.

How will this crisis transform Europe? Up to now, even though it could be improved, European coordination has been crucial. Markets speculate on the divisions perceived when intergovernmental management is chaotic. Thus, it is necessary to take steps towards mutualisation of economic risks at the same time as the monetary system is completed by means of a recognizable authority. It is urgent to rebalance both political deliberation and

${ }^{24}$ FEAETHERSTONE, K., "The Greek Sovereign Debt Crisis and EMU: A Failing State in a Skewed Regime", in Journal of Common Market Studies 2011/49, 2: pp. 193-217; DE GRAUVE, P., The Governance of a Fragile Eurozone. CEPS Working Document No. 346, 2011; EICHENGREEN, B., "European Monetary Integration with Benefit of Hindsight", in Journal of Common Market Studies 2012/50, pp. 123-136.

${ }^{25}$ MAYER, T., Europe's Unfinished Currency. The Political Economics of the Euro, Anthem Press 2012.

${ }^{26}$ EDER, K. and GIESEN, B., European Citizenship: National Legacies and Transnational Projects, OUP Oxford 2001; SCHIEK, D., LIEBERT, U. and SCHNEIDER, H. (eds.), European Economic and Social Constitutionalism after Lisbon, Cambridge University Press, 2011. 
the reality of markets. Europe is also an interesting project inasmuch as it is an attempt to build a space for political, economic and social reconciliation.

\section{European citizenship: a plurality of loyalties}

What we could call, I dare say, the European's disloyalty means in fact that, thanks to the innovation represented by Europe, we enjoy a space in which political loyalty finds itself pluralized, conditioned by the law of the state monopoly and free from it. Some of these features had taken place before, but never had these three circumstances articulated in such a balanced way and in such an original citizenship framework.

In order to understand this innovation, one needs to abandon the idea that society depends only and exclusively on the state's architecture, as this no longer enjoys the monopoly on identity, sense of belonging, acknowledgement and protection. What makes this dissociation more visible is the possibility for citizens to appeal to Community Courts against decisions taken by their own states. This alone allows us to say that, for the first time, Europe has separated human rights from nationality and citizenship. Thus, it contravenes the state's wish to be the only instance ensuring the preservation of rights.

Europe as a construction makes clear that the link between nation and democracy is context-dependant rather than conceptual, which leads us to the conclusion that wider civic identifications are possible, that the process of democratic learning can be extended beyond the nation state. We have managed to disperse sovereignty, multiply spaces for civic engagement, while promoting self-government and loyalty towards wider political sets ${ }^{27}$. This is why we are faced with the possibility of inventing a new kind of citizenship, a more complex one, which would not stem from the mere extension of the existing kinds to the European scale.

Up to now, redistributive issues and the definition of a political community have been dealt with inside the states themselves; but at the same time there is a massive redistribution on a EU scale without specific criteria of transnational legitimation. The temptation for mimesis is certainly a reason for pessimism, but there are other ways of identification and governance apart from those featured in the national state. There is no reason for thinking of democracy in wider spaces (Europe or the world) as reproduction on a different scale of the mechanisms representative of the

27 SANDEL, M., Democracy's Discontent, The Belknap Press of Harvard University Press, Cambridge, MA, 1996, p. 148. 
state. The future of the EU is not simply a matter of building a large state, be it federal or confederal, but requires the invention of new structures that lack a substantial precedent either in the experiences of different states or in organized international cooperation ${ }^{28}$.

What some call 'Europeanization' is something very different from the traditional "nation-building", and has to be reconsidered beyond the category of the national state, mostly beyond the idea that society is no more but a mere corollary of the state, and therefore has to be tamed. The issue is that one must not think of societies as fixed, delimited entities, but as transforming realities, as "emerging realities" 29 . The EU does not govern in the same way as any other state. Its peculiarity is, so to say, that it builds the spaces in which European solutions to European problems can be found. Its main challenge consists in building Europe as something to govern, and to this aim it activates a series of actors, state institutions, citizens, networks, companies... What is innovative is not as much the governance tools as the fact that what is to be governed has to be constituted. In Majone's words ${ }^{30}$ the first task governance is to build what is to be governed, in this case, European -wide activities.

One could say that Europe is a space for redefining what is common, and that European citizenship aims at the democratic configuration of that sense of common. This is difficult to identify by means of democratic deliberation, and should not be reduced to a primitive juxtaposition of interests. Here we are faced with the antagonism formulated by Benjamin Barber, when he spoke of the overlapping of individual interests, of the "mutual advantage" and "the advantage of their mutuality" 31 . The old ontological principle that states that the whole is greater than the sum of its parts is politically translated into a public sphere understood as something that does not limit itself to just balancing individual preferences. The greatness of the process of European integration lies in fact in its enormous cooperative knowledge, but also in its weakness when the sphere of implicit or merely biased accession is not transcended.

In my view, it is here that the legitimacy crisis we have been suffering from since the 90's lies, a crisis that has eroded respect for the common rules, as shown by the fate of the Stability Pact. Within a general environment that

${ }^{28}$ CONSTANTINESCO, V., "Europa fédérale ou fédération d'États-nations", in DEHOUSSE, R. (ed.), Une constitution pour l'Europe, Presses de Sciences Po, París, 2002, p. 139.

29 MELLOR, P., Religion, Realism and Social Theory, Sage, London, 2004.

30 MAJONE, G., Regulating Europe, Routledge, London, 1996, p. 59.

31 BARBER, B., Strong Democracy. Participatory Politics for a New Age, Berkeley: University of California Press, California, 1984, p. 118. 
has not particularly favoured great projects and considering a generation of politicians lacking their predecessors' vision, Europe remains at the mercy of the volatility of short-term interests and subordinated to domestic goals. Citizens do not trust a political system that they misunderstand and state governments do not trust the increasing power of the Commission. Forms of action are reduced to classical intergovernmentalism and leadership is provided by the European Council, which is formed by the heads of state and government. Little by little, a willingness to break with the delegations of power, a feature of the community method, has settled.

This is the context that fostered the need for a redefinition of Europe's own purposes and that ended up in an attempt to draw up a Constitutional Treaty. Fischer's denunciation in his famous speech in 2000 criticised the "communitarian method", that is, the idea that everything should be dependent on functional integration. But 'permissive consensus' is not sufficient when the issue is to build a political community. Pragmatism promises to make progress step by step without wasting time wondering about the overall picture of the European construction, but the matter of substance, that is, the shape of European citizenship, comes to surface when we come across the limits of an integration thought of as a technical process.

From this point of view, the Constitutional Treaty was an insufficient step. The fact that it was 'constitutional' suggested a break with the past, but it was basically a treaty and therefore retained a line of continuity and preservation of the power of states, which, in turn, did not seem to worry about anything except about ensuring that no decision affecting their essential interests could be made. Negotiation about blocking minorities and exceptions marginalized any debate on the procedures for the identification of what is common. Constitutional rhetoric was misleading, as can be seen by comparing, for example, who signed the American Constitution ("We, the people") and how, in the draft of the Constitutional Treaty that decision was in the states' hands ${ }^{32}$. The difference between a treaty and a constitution is, in fact, the same as that between a deal between states and an act of selfdetermination of the European society. The Constitutional Treaty did not involve a qualitative leap; the traces of continuity overweighed the drivers for change. In spite of this, in some countries it also raised fears and difficulties for its acceptance, as if it really was a real break with the past. One of the reasons for the constitutional failure was the gap between the emphasis of the proclamations and the modesty of real objectives. There is nothing worse than arousing fear and lack of enthusiasm at the same time.

32 DEHOUSSE, R., La fin de l'Europe, Flammarion, Paris, 2006. 
How can we get out of the current scenario? There is no doubt that the procedure for the revision of treaties should be modified, decision-making in an enlarged Union should be made more agile by spreading qualified majority voting, the European social model should be defined, and we should succeed in making the citizen find positive reasons for providing active support to one of the most spectacular enterprises in recent history. It is necessary to redefine public goods (security, social protection, economic growth...) in order to make sense of the common European space and, at the same time, design particular projects with identifiable benefits. We will need an objective of integration that is legible for the citizens, since Europe can only be credible when the action undertaken by an organ replaces that of scattered governments.

Nevertheless, the future of Europe depends ultimately upon the recovery of its original strength, which stems from the wish to put an end to the helplessness of traditional diplomacy between states. The European project would enjoy larger support if we were able to understand and explain its large innovative capacity. Rulers and citizens alike need to make the conceptual leap represented by the EU means. The former are responsible for making people understand the demands of interdependence, explaining the long-term benefits that can justify mutual concessions and immediate sacrifices. And citizens wish for choices to be made consciously and following public debate; they reject that, under the pretext of Europe or globalization, irresponsibility may gain ground or political matters may be abandoned to inertia, lacking direction. Even the 'no' is a manifestation that the European space is considered a relevant dimension of citizenship.

In any case, any strategy adopted must combine the search for consensus and convergence, without which the referendum procedure is bound to fail, and the decision-making capacity of citizens, in which the source of legitimacy lies. Vision and participation are the two main elements that need to be put at stake in what constitutes the laboratory of the largest supranational, multicultural democracy in the world.

\section{A globalized Europe: a sort of "us" without others}

When it comes to thinking of Europe it is not enough to focus on institutional structures; one has to pay attention to society. Societies are built and transformed under conditions that are neither fixed nor can be reduced to institutional structures. Europe must be understood on the basis of European society, a society that cannot be understood with the analytical procedures of states and their convergence that can no longer be understood without the reality of globalization. It is necessary to have 
a perspective over the European public space, involving overlapping and interdependence. It is common to speak about "domestic changes produced by the European integration" 33 , but the opposite process is usually forgotten: that it is the internal transformation of those societies that forces the modification of the institutional frameworks, and this social dynamics can only be explained in the global context. This is why it is more suitable to speak about "Europeanization" rather than "European integration". The former refers to society in a wide sense, and includes its global dimension; the latter seems to reduce everything to states and institutional frameworks.

In spite of the EU's regulatory power, Europeanization is taking place worldwide ${ }^{34}$. Europe is built in the midst of a process in which diverse logics intervene and projects, discourses, social patterns, and disparate imaginaries interweave. All this is taking place in a moment in which the nation state has lost the monopoly of collective action and social identifications. There exists abundance of groups, institutions and individuals that think and behave outside national states, such as migrations and diasporas, traditional social movements, regions and cities.

When the European Commission, in its Document on Governance (2001) posed the issue of citizenship and European public space, it paid little attention to this dimension, as if it was thinking of a closed, welldefined community similar to those at the basis of national states, the image of which should be replicated. Whether a European citizenship exists or not also has to be put forward in an original way; rather than a question of identity, it should be faced as a challenge linked to the civilizing mission we can face. The determination of the Commission to build an "organized civil society at a European level" must be understood within the global society it is part of. It is paradoxical to state that fostering a truly European citizenship through universal values leads to a weaker exclusive identification with Europe as such values provide reasons for European s to see themselves as part of the world, of a single humankind.

What is most interesting about the European construction is that it allows going beyond the fiction involved by the fact that society can be stately built, independently from other societies. There is not a single European civil society that is the result from the mere aggregation of national societies disconnected from the rest of the world. European society forms part of a global one. It is a mistake to over-emphasize the difference between Europe and the rest of the world, or to think that all integration strategy can be justified as a defence from a world considered a threatening

33 VINK, M., "What is European ization? And other questions on new research agenda", in European Political Science 3 (1), 2003, pp. 63-74.

34 DELANTY, G. and RUMFORD, C., op. cit, p. 155. 
reality. If there is something that justifies the European experiment, it is the fact that it encourages a kind of identity that not only does require the elimination of its internal diversity but also does not need to oppose others to gain its own affirmation: it is a sort of "us" without others. One of Europe's fundamental values is that identification with one's own becomes less exclusive and allows a great complementarity.

The political construction of Europe is singular in a way that makes it different from all the projects of national construction. It is probably the first political body shaped without the need for a kind of ideological patriotism that demands a well-delimited, homogeneous people, a common origin, a common language and culture, and some sort of external enemy that serves internal cohesion. In spite of the abundant rhetoric in that direction, the antagonism with the United States tries to endorse Europe with an unnecessary legitimacy, as Europe is rooted in other kinds of values. Unlike what has been habitual in the configuration of nations, the European project does not demand the dramatization of external danger in order to ensure inner cohesion.

Europe cannot be thought of as an entity away from the world. This interweaving has been a constant feature in history; here the awareness of being linked to the rest of the world has always been particularly intense. This reference, which in the past was driven by a civilizing will that was at the same time commercial and colonial, has provided Europe with a strength that continuously takes it away from its potential isolation. Therefore, one can state that the impact of globalization does not mean a particularly original break with history. This "cosmopolitan Europe" 35 becomes emphasized in the European Union project. Against the conception of Europe as an autocratic entity clearly separated from the rest of the world and competing against it, the European experiment has no other justification than to represent the embryo of genuine cosmopolitics. Europe, which has always enjoyed an expansive culture, can find here a horizon of meaning. Against the stereotype that presents globalization as a threat, against the warning that Europe should not become the Trojan horse of globalization - as said by Nicolas Sarkozy during the French presidential election campaign in 2007, and, by the way, something a large section of the left agreed with, since the Socialist Party itself had used that expression in their Dijon Congress in 2003-, it is urgent to "de-provincialize Europe"36, that is, to set it in the context it belongs to at the same time it faces its current responsibilities.

35 BECK, U. and GRANDE, E., op. cit.

${ }^{36}$ CHAKARBARTY, D., Deprovincializing Europe: Postcolonial Thought and Historical Difference, Princeton University Press, 2000. 
The European Union reveals, even though in an incipient way, that globalization is not a threat for democracy, but an opportunity to expand it beyond the limits of the nation state. "Europe is an especially intense way to elaborate a global system" 37 , a miniature "world polity". Globalization, rather than a threat, challenge or catalyst, must be seen as a possibility to define the European project in global terms. It does not so much mean taking sides as a global actor as promoting a different way of organizing the relationships between the actors. We are trying to look for the meaning of society in a world in which social coherence, democratic participation and political legitimacy are being redefined.

Government practices of the European Union develop a series of universal provisions: the ability to see the very community from a certain distance, the acceptance of limitations, mutual trust, willingness to cooperate, and a sense of transnational solidarity ${ }^{38}$. Europe is not an example because of some sort of superiority, but because the European public space represents the fact that most political decisions cannot be adopted without considering whether they are in keeping with the interests of others. In this sense, Europe can be considered a paradigm of the new politics demanded by an interdependent world. "Europe provides a modern experimentation of the shaping of a truly 'multipolar' world (...). It is, no doubt, one of the messages the political Europe can propose: being multipolar itself, it can foster this kind of organization; by projecting its own internal practice outwards it can contribute to "civilizing' globalization" 39 . The European process of political integration is an unprecedented response, maybe an example one day, to the current circumstances conditioning the exercise of power in the world.

\section{Conclusion}

Only a European Union released from the categories with which we are used to thinking of the national state can make intelligible what is at stake in the current European experiment. In this paper we have analyzed such innovation in regard to its geographical and historical reality, as

${ }^{37}$ MEYER, J., "The European Union and the globalization of culture", in ANDERSEN, S. (ed.), Institutional Approaches to the European Union: Arena Report, No. 3/2001, Oslo, 2002, p. 238.

38 MAGNETTE, P., Au nom des peuples. Le malentendu constitucional européen, Cerf, Paris, 2006, p. 154.

39 FOUCHER, M., La République européenne, Belin, Paris, 2000, p. 137. 
well as its governance tools and its integration into the broader process of globalization. In the future of the European Union many important things for the future of this region of the world will be settled, but also many aspirations of universal validity: it basically makes sense to wait for the possibility of shaping something like a democracy beyond the nation state and new relationships between the stakeholders to be involved in global governance. 